\title{
28. COMPUTED TOMOGRAPHY SCAN ANALYSIS OF SITE 941 CORES, WESTERN MASS-TRANSPORT DEPOSIT, AMAZON FAN ${ }^{1}$
}

\author{
Wonn Soh ${ }^{2}$
}

\begin{abstract}
X-ray computed tomography $(\mathrm{CT})$ and pore-water chemistry analyses were performed using whole round-core samples from the regionally extensive Western Mass-Transport Deposit (WMTD), Site 941 of Ocean Drilling Program (ODP) Leg 155, on the Amazon Fan. Here, the CT value has a good correlation with the bulk density and water content of the sediment. The CT image shows a plume-shaped, fluidized structure with gas bubbles in the mud sediment, Sample 155-941B-6H-4, 0-20 cm, at $\sim 47$ meters below seafloor, at the top of a 2-m-thick soupy and gassy sediment interval. Significant increase in the water content was recognized in the fluidized sediment when compared to those of the surrounding unfluidized sediments. The content coincided with the fresh-water dilution estimated from the anomalous pore-water chemistry. The fluidization was thus caused by the dissociation of gas hydrate. The quantitative CT value analysis allows us to estimate that the percentage of gas hydrate content reaches $\sim 10 \mathrm{vol} \%$ of the fluidized sediment (17.5 vol\% of the pore space). This content seems to be equivalent to the highest contents of the gas hydrate above bottom-simulating reflectors (BSRs) reported from other hydrate regions. BSRs underlie parts of the continental slope updip from the WMTD. The 2-m-thick soupy and gassy sediment is inferred to be derived from a part of "missing" sediment interpreted from seismic-reflection profiles of the source area of the WMTD that is bounded by scarps up to $200 \mathrm{~m}$ high. Furthermore, the disassociation of gas hydrate should be the most important trigger mechanism for causing the regionally extensive slope failure that produced the WMTD.
\end{abstract}

\section{INTRODUCTION}

Submarine failures are an important means of sediment transfer from the continental slope to deep water. Mass-transport deposits (MTDs) as products of submarine failure, are an important fan constituent and a key agent in shaping fan morphology and stratigraphy, particularly in the long-lived deep-water fans (Damuth and Embley, 1981). A few previous studies, however, have paid attention to the origin and process of the MTDs in deep-water fans (e.g., Galloway et al., 1991). Multifold seismic data for the Mississippi Fan indicate that the "mass transport complex" occurs at the base of sequences defined within a sequence stratigraphic model (Weimer, 1989). This complex is overlain and/or onlapped by channel and levee sediments. To date, the relationship between sea-level change and the formation of debris-flow deposits is still uncertain because a precise and independently dated correlation between sea-level changes and formation of debris flows has been lacking (Shipboard Scientific Party, 1995a).

Detailed mapping of the Amazon Fan with seismic-reflection profiles, long-range side-scan sonar (GLORIA), and SeaBeam bathymetry have shown the development of the extensive MTDs of more than 50,000 km ${ }^{3}$ (Damuth et al., 1983; Damuth and Flood, 1985; Flood and Damuth, 1987; Manley and Flood, 1988; Damuth et al., 1988; Flood et al., 1991) (Figs. 1, 2). Two surficial MTDs, the western MTD (WMTD) and the eastern MTD (EMTD), and two buried MTDs, Unit R (URMTD) and the bottom MTD (BMTD), have been identified from the seismic profile record in the Amazon Fan (e.g., Manley and Flood, 1988). Although these deposits are termed "debris-flow deposits" in the recent literature, I will use the term "mass-transport deposit" as suggested by Piper et al. (Chapter 6, this volume), because they are composed of complex deposits located between the slump and slide deposits and debris-flow deposits.

During Leg 155, three MTDs, the BMTD, Unit R, and the WMTD, were all sampled to clarify the sedimentary facies and the

Flood, R.D., Piper, D.J.W., Klaus, A., and Peterson, L.C. (Eds.), 1997. Proc. ODP, Sci. Results, 155: College Station, TX (Ocean Drilling Program).

${ }^{2}$ Department of Earth and Planetary Sciences, Kyushu University, Fukuoka, Japan. soh@planet.geo.kyushu-u.ac.jp depositional age and to examine the relationship between debris flows and sea-level change in the Amazon Fan (Shipboard Scientific Party, 1995a). The BMTD overlies middle Pleistocene mottled silty clay at the top of the Bottom Levee Complex (Site 933), and its aerial distribution remains uncertain. The BMTD comprises chaotic silty clay with deformed mud clasts containing terrigenous organic matter as was expected from the seismic facies. The URMTD consists of dark gray mud, much of which appears deformed (Site 936). It filled the pre-existing topographic lows together with a limited amount of erosion, and overlies the Lower and Middle Levee Complexes on the basis of the seismic profiles. Based on apparent continuity in a seismic profile and the consistent age of the underlying foraminifer-nannofossil-rich clay layer, Piper et al. (Chapter 39, this volume) suggest that the BMTD and the URMTD are part of a single MTD. The depositional timing was thought to be in the regressive stage of sea level because of the age of overlying sediment. However, an erosional feature located between both MTDs and the underlying foraminifer-nannofossil-rich clay makes precise age determination difficult.

The WMTD, on the other hand, occurs at or very near the presentday seafloor on the western part of the Amazon Fan. It is conformably overlain by a condensed section of the hemipelagic sediments (Unit II and the uppermost $5 \mathrm{~m}$ of Unit III) and the calcareous ooze (Unit I), as shown in the cores obtained from Hole 941A (Shipboard Scientific Party, 1995c). The depositional age of the hemipelagic sediment overlying the WMTD is $18 \mathrm{ka}$. The seismic profiles tentatively allow us to correlate the WMTD with the Purple Channel-levee System $22 \mathrm{ka}$ in age. Hence, the timing of the formation of the WMTD should be during the last glacial maximum (LGM) or during the preceding sea-level fall (Piper et al., Chapter 39, this volume).

Fluidized sediments obtained on Leg 155 were described as soupy and/or mousse-like, and their amounts are significant in the WMTD (Fig. 3) when compared to those of the channel-levee complex of the Amazon Fan. For example, more than $15 \%$ of the sediments obtained from the advanced hydraulic piston core (APC) Hole 941B drilled in the WMTD are fluidized. In particular, a 2-m-thick layer of soupy sediment with signs of extreme gas expansion and a honeycomb structure was recognized between 47 and 49 meters below seafloor (mbsf), and was, in turn, overlain by $2 \mathrm{~m}$ of mousse-like sediment. 


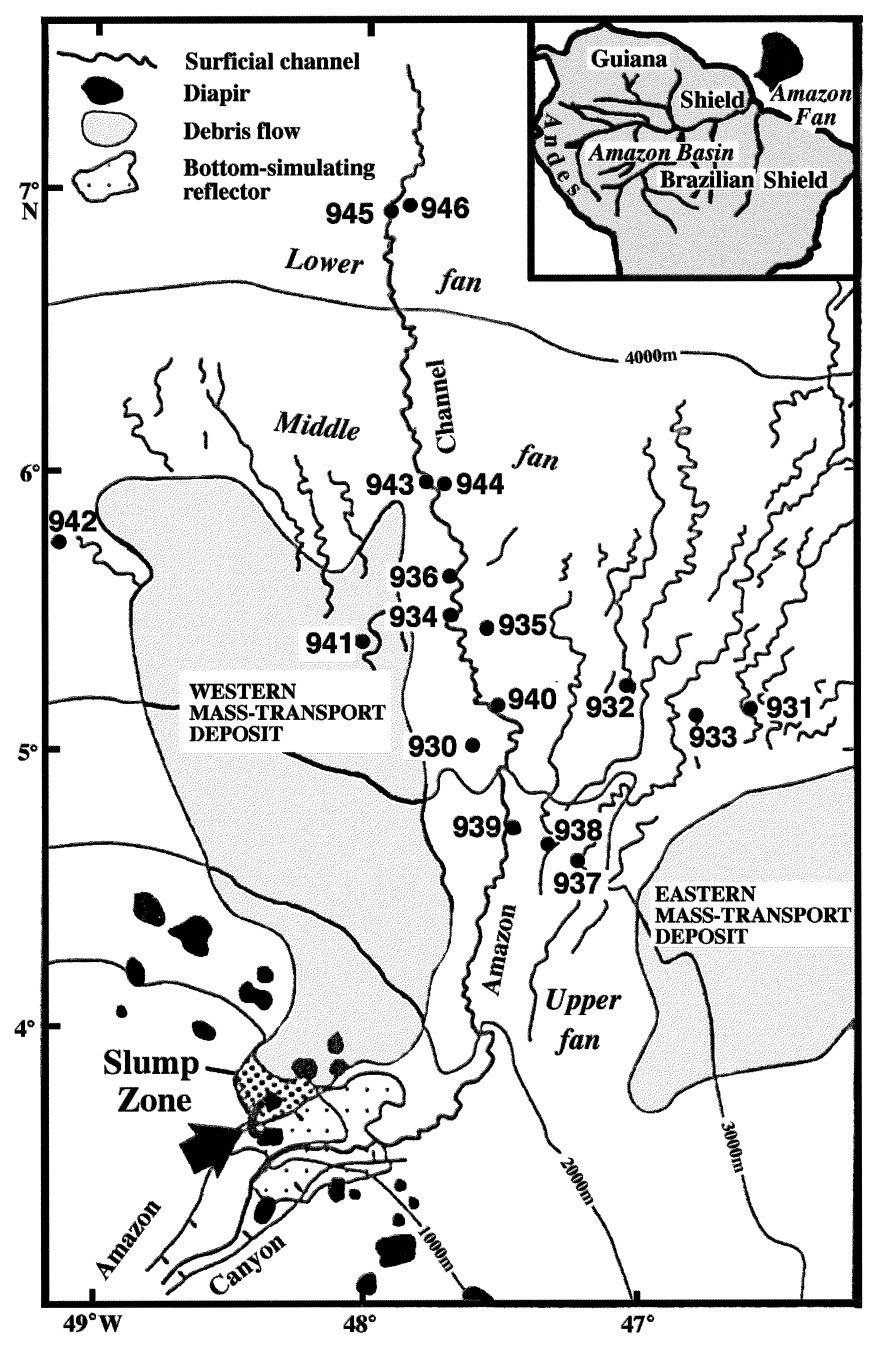

Figure 1. Location map showing the Western Mass-Transport Deposit with Site 941. In and around the source area of the WMTD, a bottom-simulating reflector, represented by the gray pattern, is developed. A curved line, shown by tip of arrow, is the location of the seismic line shown in Figure 11 (modified from Manley and Flood, 1988, and Damuth et al., 1988).

Recently, the origin of the fluidized sediments with gas has received much attention in relation to gas hydrate disassociation (e.g., Shipboard Scientific Party, 1994). When considering that disassociation of gas hydrate is one of the most important trigger mechanisms for causing slope failure in passive margins (Kayen and Lee, 1993), the nature of the fluidized sediment provides a clue to understanding the origin of the slope failure that produced the mass transport. In this paper, I show computed tomography (CT) images of core samples obtained from Site 941 and examine the physical properties of fluidized sediment in the WMTD using CT images to reveal the presence of gas hydrate in the WMTD. The initial conditions when the mass transport occurred in the continental slope are also discussed.

\section{METHODS AND SAMPLES}

An X-ray CT scanner is a device used for reconstructing the image of an object penetrated by X-rays, using the X-ray linear attenuation coefficients calculated from absorption or scattering. For the imaging, the linear attenuation coefficients transfer to

$$
\text { CT value }(\mathrm{N}=1000(\mu-\mu \mathrm{w}) / \mu \mathrm{w}) \text {, }
$$

where $\mu \mathrm{w}$ is the $\mathrm{X}$-ray linear attenuation coefficient of standard water, $20.4 \mathrm{~m}^{-1}$ in the device, and $\mu$ is the X-ray linear attenuation coefficient of the sample. Several published articles are available about the CT scan method applied to core samples (e.g., Hunt et al., 1988; Holler and Kogler, 1990; Orsi et al., 1993). The CT scanner used in this study is a Toshiba X-force, housed in the Technical Research Center, Japan National Oil Corporation, Chiba. The scanner is a third generation CT with $836 \mathrm{Xe}$ gas detectors in the detector array. A 120-peak kV X-ray beam was used. One pixel, in this study, expresses an average of a unit volume with an area of $0.35 \mathrm{~mm}^{2}$ wide and a thickness of $2.0 \mathrm{~mm}$. The data are displayed on $512 \times 512$ pixels on a gray-level viewing system with the brighter parts representing higher $\mathrm{CT}$ values.

Two holes were cored in Site 941, which penetrated the WMTD; Hole 941B was offset $\sim 500 \mathrm{~m}$ from Hole 941A. The MTDs from these two holes are characterized by abrupt changes in lithology and color, structures indicative of deformation such as folds and faults, discordant stratal relationships between dipping laminae, beds and lithologic contacts, and the occurrence of various-sized clasts. Most of the deposits are composed of mud clasts and are clast supported with little apparent matrix. The clasts commonly show a variety of colors, textures, and compositions with high abundance of bathyal benthic foraminifers and a low abundance of abyssal benthic foraminifers. A few clasts in Hole 941B contain Miocene nannofossils. The thickness of the WMTD deduced from Hole 941A was $124.4 \mathrm{~m}$.

Deformation and disturbance of sediment clearly resulted from the coring process. Expanding gas extruded from the pore water during core recovery disrupted the sediments in many of the Leg 155 cores, including Site 941 cores. The expansion effects are more extensive, resulting in widespread modification of primary sedimentary structures, and are later described in detail. Some sediment was also lost from the core sections as well as the displacement of intervals of more consolidated clayey sediment along the core liner as gas pressure was released. This sediment loss resulted in the expansion of void space within the core sample. The expansion of the void in the core liner significantly influenced the shipboard multisensor track (MST) data. For example, the bulk density obtained from the gammaray attenuation porosity evaluator (GRAPE) dropped abruptly from 1.70 to $1.35 \mathrm{~g} / \mathrm{cm}^{3}$ with the first appearance of voids resulting from gas expansion ( $\sim 5 \mathrm{mbsf})$, and the GRAPE value did not recover with increasing depth. Three core samples from Hole $941 \mathrm{~A}$ and 15 core samples from Hole 941B were scanned in this study (Table 1). These samples consisted of 20-cm-long whole-round cores in the core liners that were coated with paraffin to prevent dehydration and then kept at $4^{\circ}-5^{\circ} \mathrm{C}$ during transport to the laboratory. Sixteen MTD samples and two levee sediments were scanned. All whole-round core samples scanned in this study were selected using the shipboard MST data so as to exclude obvious artifacts resulting from the gas expansion. As a result, the CT images presented here are images with fewer drilling-induced artifacts than ordinary.

To exclude the influence of artifacts as much as possible, I adopted CT values obtained by using a fixed region of interest (ROI) from an area within a sample. The ROI was selected with care from the homogeneous domains in the CT value, judging from the CT value histogram. Domains with bimodal modes in the CT values were excluded from the ROI. Moreover, the ROI was selected away from the margin of core sample to avoid the influence of "beam-hardening," and domains showing CT values abnormally higher were also deliberately excluded from the ROI. The dimensions of the ROI adopted here range from $68.3 \mathrm{~mm}^{2}$ to $1384.9 \mathrm{~mm}^{2}$ over a region of suitable size. The results of repeated scanning demonstrate good reproducibility of CT values. The wet bulk density and water content data (Table 1) collected as part of the shipboard index properties analyses on Leg 155 (Shipboard Scientific Party, 1955c) were utilized to show the relationship between the CT value, bulk density, and water content. I used the shipboard wet bulk density data obtained from discrete samples that were usually taken within $70 \mathrm{~cm}$ and commonly within 30 $\mathrm{cm}$ of the sites of the whole-round core samples for the CT scan study. 


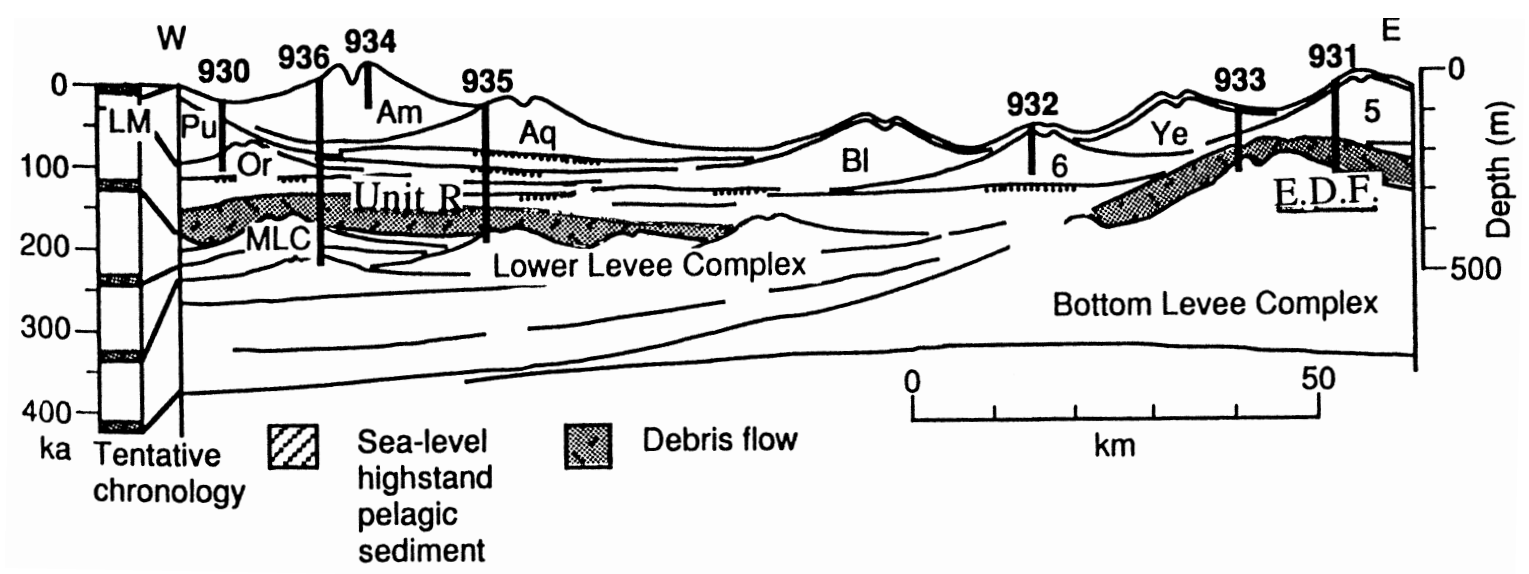

Figure 2. Schematic cross-section of the upper Quaternary sediments of the Amazon Fan. Stacked channel-levee systems result from aggradation by turbidites. Groups of stacked channel-levee systems make up levee complexes (MLC = Middle Levee Complex), and they are divided by a regionally extensive debris-flow deposit. The distribution and depositional age of two MTDs, URMTD and BMTD, are illustrated. The Western Debris-Flow deposit is the youngest debris-flow deposit. Am, Aq, Pu, B1, Ye, 5, Or, and 6 signify successively older channel-levee systems of the Upper Levee Complex. LM = Lake Mungo Excursion (30 ka).

\section{RESULTS \\ CT Scan Image}

The CT scan images display internal sedimentary structures as well as drilling-induced artifacts. The sedimentary structures can be divided into two types based on the CT images; structureless mudstone and banded siltstone and mudstone (Fig. 4). In turn, there are two different structureless massive sediments from observing the CT images. These are clasts in the debris flow and faintly mottled and color-banded silty clay. The structureless mudstones consist of faintly mottled and color-banded silty clay that commonly contains numerous bright spots that are interpreted as authigenic minerals, probably hydrotroilite. The clasts of the MTD normally do not contain any bright spots, although they are similar in texture. The banded siltstone and mudstone, on the other hand, developed only in the hemipelagic or levee sediments (Fig. 4). The banded siltstone and mudstone is graded, although the thickness of the band varies, ranging from millimeters to a few centimeters. The bases of the bands are commonly distinct and sharp when compared to the tops, even in the CT scan image. This suggests that they contain thin-bedded turbidites. Sand layers can be easily identified from the CT image pattern. Deformation structures, excluding drilling-induced artifacts, are rarely recognized. One exception is the crenulated deformations recognized in the sample from the interval from 58.6 to $58.8 \mathrm{mbsf}$, Sample 155-941B-7H-5, 0-20 cm (Fig. 5). The deformed bedding dips steeply $\left(>60^{\circ}\right)$ and can be interpreted as tight folds formed during slumping or sliding of the sediments.

Most of the sediment samples obtained from Site 941 suffered from drilling-induced artifacts (cf. Shipboard Scientific Party, 1995a). Many structures resulting from these artifacts were observed in the CT images, and they can be grouped into four types: open fracture, shear, contortion, and fluidization. Among them, the open fracture is commonly developed through the whole-round core samples. The open fracture consists of closely spaced millimeter- to centimeter-scale fractures regularly formed perpendicular to the core axis. The open fracture is interpreted to be formed by gas expansion (mostly methane) originally dissolved in the pore water. The shearing and contortion of the sediments are artifacts that are caused by the extended core barrel (XCB) coring, as they are common features in all XCB core samples, whereas they are not observed in the APC samples. Figure 6 shows the CT image of the core sample obtained from the interval from 162.8 to 163.0 mbsf, Sample 155-941A-18X-3, 130$150 \mathrm{~cm}$. This image clearly shows rotational shearing with open sigmoidal fractures that have disturbed the sedimentary structures. Similar sigmoidal fractures are commonly developed in the XCB cores.
XCB-induced shearing appears to have modified the sedimentary structures and fabric more than was thought aboard ship from the split-core observations. It should be emphasized that the sediment samples taken by XCB should be treated with caution. The XCB-induced artifacts were obviously cut by gas expansion-induced fractures, thus the gas expansion-induced fractures formed later than the XCB-induced artifacts. Fluidized sediment with spherical bubbles was identified on the CT image in the interval from 48.4 to $48.6 \mathrm{mbsf}$, Sample 155-941B-6H-4, 0-20 cm (Fig. 7). This corresponds to the mousse-like part seen at the top of the $\sim 2$-m-thick soupy (and/or mousse-like) sediment interval from 48.4 to $50.4 \mathrm{mbsf}$. The extreme gas expansion and "honeycomb" structures are clearly developed in the soupy sediment that is intercalated between the more consolidated sediments below and above. From the CT image taken from Section 155-941B-6H-4, two units are identified: (1) the fluidized unit in the central part of the sample; and (2) the unfluidized unit with gas expansion-induced open fractures surrounding the fluidized center. The fluidized unit is less bright than the surrounding unfluidized unit, and the spherical bubbles are concentrated toward the top of the CT image. The fluidized unit is plume-shaped, suggesting that the fluidized unit intruded into the unfluidized unit. Careful observation indicates an "oatmeal-like" texture that is a mixture comprising the fluidized materials and a small number of small unfluidized patches that can be identified within the fluidized unit. This can be seen along the margin of the fluidized unit (Fig. 7). Furthermore, the boundary of the fluidized unit cuts diagonally across the extension of the gas expansion-induced open fractures in the unfluidized part, suggesting that the fluidization must have taken place no earlier than the formation of the gas expansion-induced open fractures.

\section{Quantitative Analysis for Fluidized Sediment Relationships of CT Values, Bulk Density, and Water Content}

The average CT value is plotted vs. bulk density and water content in Figures 8 and 9. The relationship between the CT value and wet bulk density shows a positive linear correlation, whereas the relationship between the CT value and water content shows a negative linear correlation. The resulting relationship between the wet bulk density $\left(\rho_{\text {sample: }} \mathrm{g} / \mathrm{cm}^{3}\right)$ and the CT value can be approximated by

$$
\text { CT value }=1313 \rho_{\text {sample }}-1322\left(\mathrm{R}^{2}=0.965\right)
$$

The response of CT scanners to biological materials with X-ray attenuation near that of water is fairly well known (McCullough, 1975 ) and shows that a density increase of $0.01 \mathrm{~g} / \mathrm{cm}^{3}$ corresponds to 
Figure 3. Composite stratigraphic section for Site 941 showing core recovery, a simplified summary of lithology, depth of unit boundaries, age, graphic section with bedding characteristics, soupy and/or mousse-like sediment horizon of Hole 941B, and the sampling site for CT scan analysis. Bars with circles $=$ data from Hole $941 \mathrm{~A}$; bars with square boxes $=$ data from Hole 941B.

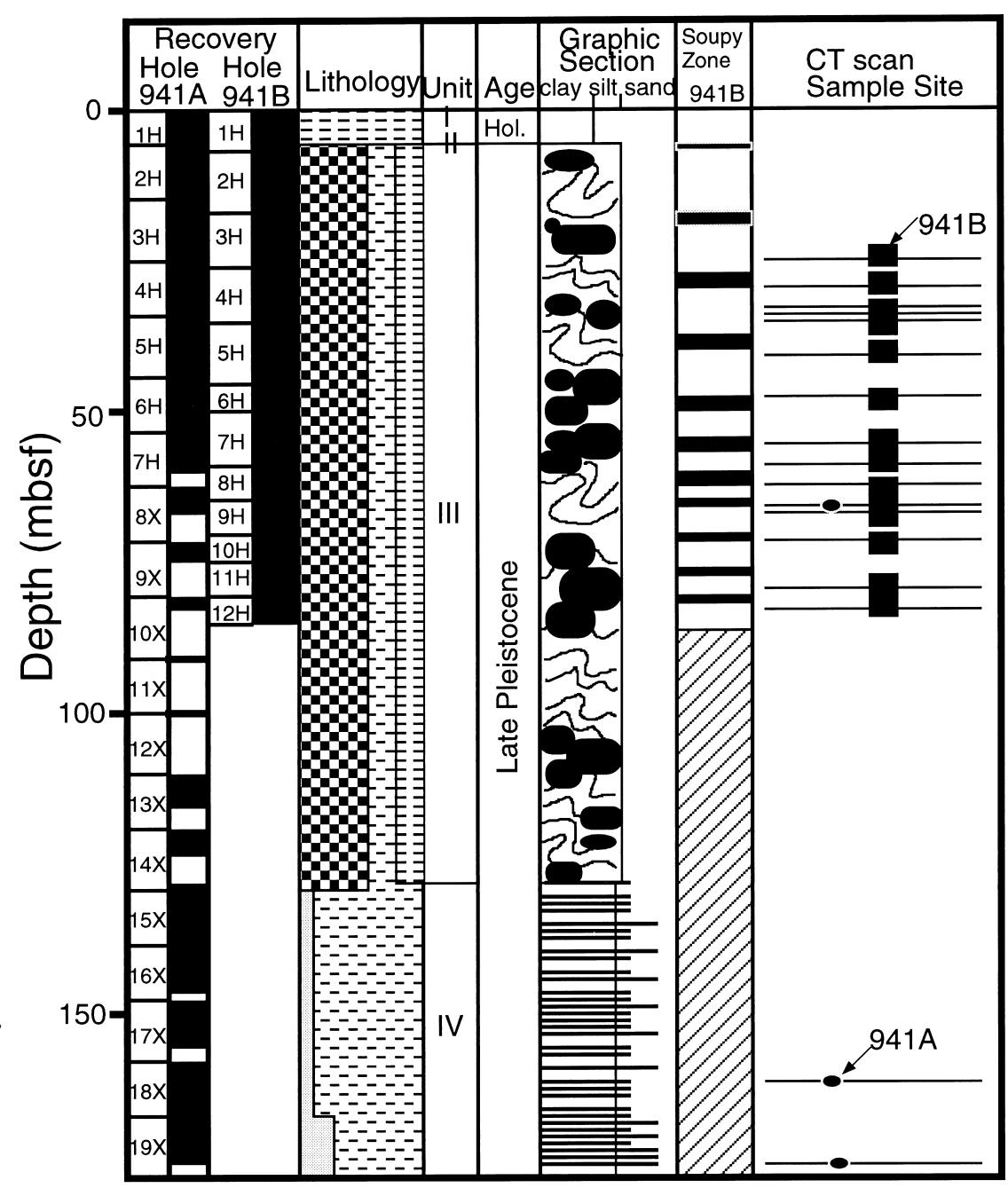

Table 1. List of CT values and physical properties for Site 941.

\begin{tabular}{|c|c|c|c|c|c|c|c|c|c|c|c|}
\hline $\begin{array}{l}\text { Core, section, } \\
\text { interval }(\mathrm{cm})\end{array}$ & Lithology & $\begin{array}{l}\text { Depth } \\
\text { (mbsf) }\end{array}$ & $\begin{array}{c}\mathrm{CT} \\
\text { value }\end{array}$ & $\begin{array}{l}\text { Standard } \\
\text { deviation }\end{array}$ & $\begin{array}{c}\text { Confidence } \\
(0.05)\end{array}$ & $\begin{array}{c}\text { Water } \\
\text { content } \\
(\%)\end{array}$ & $\begin{array}{c}\text { Wet } \\
\text { density } \\
\left(\mathrm{g} / \mathrm{cm}^{3}\right)\end{array}$ & $\begin{array}{c}\text { Grain } \\
\text { density } \\
\left(\mathrm{g} / \mathrm{cm}^{3}\right)\end{array}$ & $\begin{array}{c}\text { Dry } \\
\text { density } \\
\left(\mathrm{g} / \mathrm{cm}^{3}\right)\end{array}$ & $\begin{array}{c}\text { Porosity } \\
(\%)\end{array}$ & $\begin{array}{l}\text { Void } \\
\text { ratio }\end{array}$ \\
\hline \multicolumn{12}{|l|}{ 155-941A- } \\
\hline $8 X-3,68-88$ & D.F. & 63.0 & 1226.9 & 19.7 & 2.7 & 27.3 & 1.93 & 2.77 & 1.40 & 50.4 & 1.02 \\
\hline $18 X-3,130-150$ & D.F. & 162.8 & & & & 26.3 & 1.96 & 2.71 & 1.45 & 48.6 & 0.95 \\
\hline $19 X-5,117-137$ & D.F. & 176.4 & 1312.1 & 10.5 & 1.4 & 25.8 & 1.99 & 2.76 & 1.48 & 48.3 & 0.94 \\
\hline \multicolumn{12}{|l|}{ 155-941B- } \\
\hline $3 \mathrm{H}-6,130-150$ & D.F. & 22.2 & 989.2 & 38.5 & 5.2 & 35.1 & 1.75 & 2.72 & 1.13 & 58.9 & 1.43 \\
\hline $4 \mathrm{H}-3,0-20$ & D.F. & 28.9 & 1057.6 & 113.2 & 15.4 & 32.6 & 1.83 & 2.79 & 1.23 & 56.8 & 1.31 \\
\hline $4 \mathrm{H}-5,123-143$ & D.F. & 30.7 & 1051.7 & 50.7 & 6.9 & 32.7 & 1.83 & 2.80 & 1.23 & 57.0 & 1.33 \\
\hline $4 \mathrm{H}-6,130-150$ & D.F. & 32.2 & 1114.9 & 23.8 & 3.2 & 31.5 & 1.84 & 2.75 & 1.26 & 55.2 & 1.23 \\
\hline $4 \mathrm{H}-7,130-150$ & D.F. & 33.7 & 1086.3 & 19.9 & 2.7 & 32.3 & 1.83 & 2.77 & 1.24 & 56.2 & 1.28 \\
\hline $5 \mathrm{H}-4,0-20$ & D.F. & 39.0 & 1069.6 & 34.5 & 4.7 & 32.3 & 1.84 & 2.80 & 1.25 & 56.6 & 1.30 \\
\hline $6 \mathrm{H}-4,0-20$ & D.F. & 48.4 & 968.7 & 32.3 & 4.4 & 36.4 & 1.74 & 2.73 & 1.11 & 60.4 & 1.53 \\
\hline $7 \mathrm{H}-7,0-20$ & D.F. & 58.6 & 1170.1 & 12.2 & 1.7 & 28.9 & 1.88 & 2.75 & 1.34 & 52.1 & 1.09 \\
\hline $7 \mathrm{H}-5,130-150$ & D.F. & 56.9 & 1282.5 & 19.5 & 2.6 & 24.8 & 1.98 & 2.74 & 1.49 & 46.8 & 0.88 \\
\hline $8 \mathrm{H}-3,130-150$ & D.F. & 62.6 & 1229.1 & 35.4 & 4.8 & 26.9 & 1.95 & 2.82 & 1.43 & 50.3 & 1.01 \\
\hline $8 \mathrm{H}-5,130-150$ & D.F. & 64.4 & 1254.0 & 14.0 & 1.9 & 25.7 & 1.99 & 2.80 & 1.48 & 48.6 & 0.94 \\
\hline $9 \mathrm{H}-3,130-150$ & D.F. & 68.4 & 1171.0 & 14.2 & 1.9 & 29.3 & 1.90 & 2.72 & 1.34 & 52.4 & 1.10 \\
\hline $10 \mathrm{H}-2,130-150$ & D.F. & 72.2 & 1233.1 & 16.6 & 2.2 & 28.9 & 1.93 & 2.79 & 1.38 & 52.5 & 1.11 \\
\hline $11 \mathrm{H}-6,0-29$ & D.F. & 80.2 & 1223.5 & 39.1 & 5.3 & 28.0 & 1.93 & 2.72 & 1.39 & 50.8 & 1.03 \\
\hline $12 \mathrm{H}-3,130-150$ & D.F. & 83.1 & 1208.6 & 31.7 & 4.3 & 26.9 & 1.93 & 2.72 & 1.41 & 49.4 & 0.98 \\
\hline
\end{tabular}

Note: $\mathrm{CT}=$ computed tomography; D.F. $=$ debris flow.

an increase of 10 units in the CT value. Device response to denser materials and those of different composition, such as soils and sediments, however, is less certain (e.g., Petrovic et al., 1982; Soh et al., 1993). In this study, a density increase of $0.01 \mathrm{~g} / \mathrm{cm}^{3}$ results in a corresponding increase of 13.1 units in the $\mathrm{CT}$ value. This is higher than that of biological materials, but similar to those of denser sediments.
For example, Orsi et al. (1993) reported an increase of 12.7 units in the CT value for a shallow-water core sample collected from the Louisiana continental shelf. The difference could be due to differences in the chemical composition, because the attenuation coefficient is a function of effective atomic number of an absorbing material when density and photon energy are held constant (Pogossian et al., 1977). 


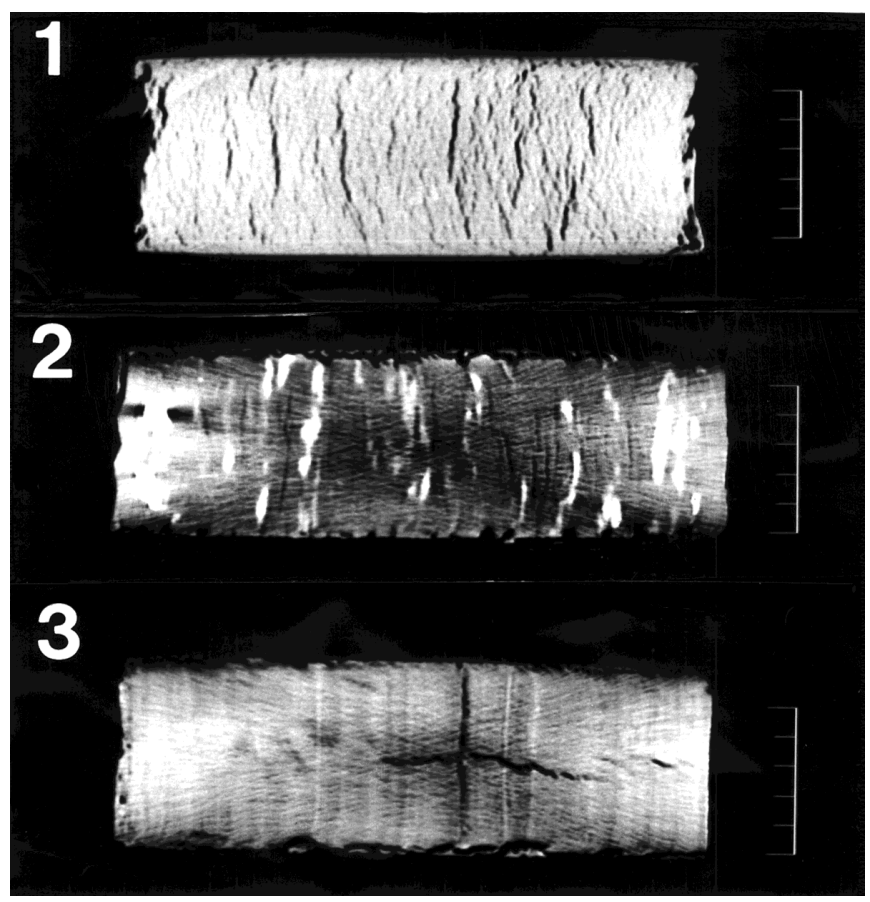

Figure 4. Three types of CT scan images. The sedimentary structure of $\mathbf{1}$ and $\mathbf{2}$ is structureless, whereas $\mathbf{3}$ is banded. There are many open fissures because of gas expansion, but along the axis fissures in $\mathbf{3}$ is another kind of fissure associated with XCB core disturbance. Samples (1) 155-941B-3H-6, 130$150 \mathrm{~cm}$, (2) 155-931B-39X-2, 130-150 cm, and (3) 155-941B-18X-3, 130$150 \mathrm{~cm}$.

In particular, the difference in content of high atomic number elements influences the CT value of the sample even if the bulk density is unchanged (cf. Anderson et al., 1988; Boespflug et al., 1995).

In addition, it is proposed that the difference in chemical composition in the samples influences the adequacy of Equation 2. At present, three mud samples obtained from the WMTD and one sample from the underlying levee sediment have been examined (table 9 in Shipboard Scientific Party, 1995c). These data indicate that the chemical composition in the mud sediments is similar. This is also supported by the fact that the clay mineral compositions of the 11 samples obtained from the WMTD and the levee sediment seem to be almost constant (cf. table 2 in Shipboard Scientific Party, 1995c). Among the major elements of the sediment, $\mathrm{Fe}$ and $\mathrm{Ti}$ are most likely to be particularly important as high atomic number elements that will influence the CT value. The content of $\mathrm{Fe}_{2} \mathrm{O}_{3}$, for example, ranges from 7.75 to $8.40 \mathrm{wt} \%$, and the $\mathrm{TiO}_{2}$ content is relatively small, ranging from 0.94 to $1.04 \mathrm{wt} \%$; therefore it is important to consider the influence of the variation of Fe content in the samples. Using the empirical relationship between the linear X-ray attenuation coefficient and Fe content (fig. 6 in Anderson et al., 1988) enables us to estimate the increase in CT value with the increase of the Fe content. As a result, the increase of $0.65 \mathrm{wt} \%$, the difference between $7.75 \mathrm{wt} \%$ and $8.40 \mathrm{wt} \%$ in the $\mathrm{Fe}_{2} \mathrm{O}_{3}$ content, corresponds to the increase of 16 units in the CT value, which corresponds to an error of $0.013 \mathrm{~g} / \mathrm{cm}^{3}$ to the correct bulk density. Hence, the differences in composition of the sediments would probably not have a major impact on the bulk density determined from the CT values.

There is also a good relationship between the CT value and water content of the samples as plotted in Figure 9. Because the relationship between bulk density and water content $(\omega)$ shows a good negative correlation, the CT value of the sediment should be mainly governed by water content included in the sediment. The relation was found to be

$$
\text { CT value }=-29.45 \omega+2031\left(R^{2}=0.956\right)
$$

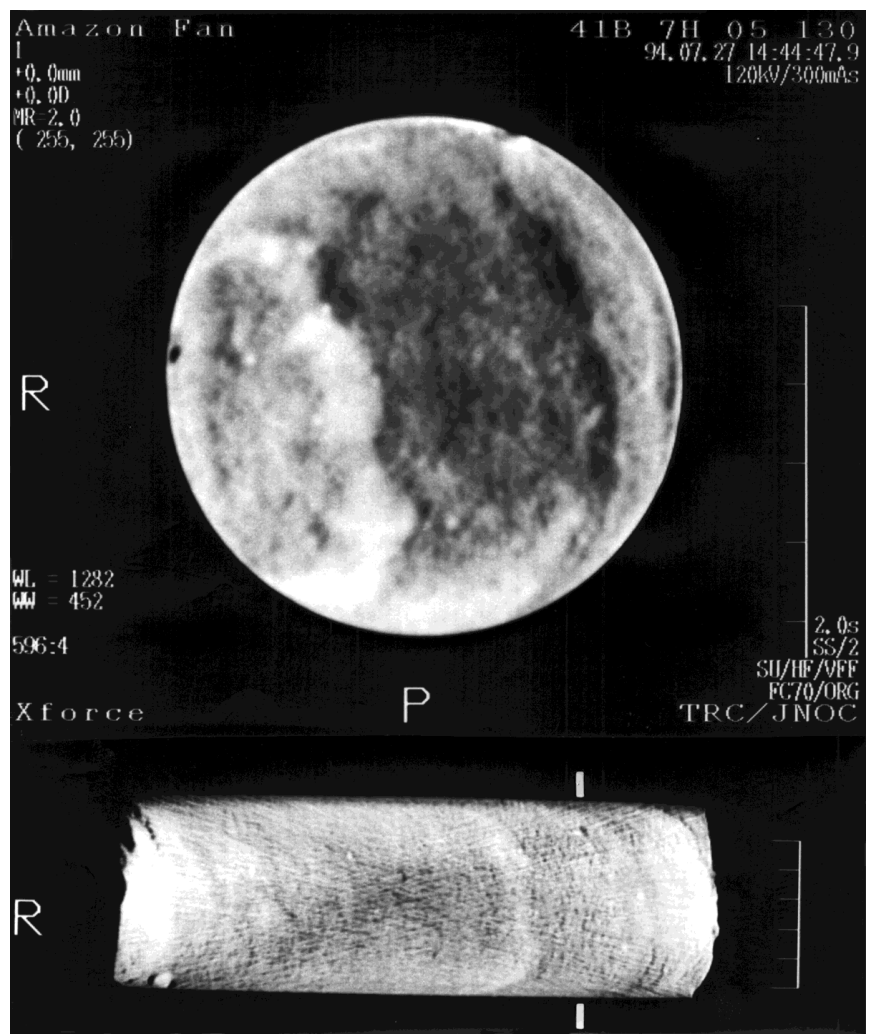

Figure 5. CT images showing crenulated deformation. The upper CT image is the vertical profile, and the lower image is the longitudinal profile of Sample $155-941 \mathrm{~B}-7 \mathrm{H}-5,130-150 \mathrm{~cm}$. Location of the vertical profile is shown in the longitudinal profile. Both images show that the deformed bedding dips steeply. Window width $=452$; window level $=1282$.

Figure 10 shows the histogram of CT values, pixel by pixel, obtained from the bubble within the fluidized part of Section 155-941B$6 \mathrm{H}-4$. Most of the CT values are negative. The small peak around 0 shows the presence of water, because 0 unit in the CT value corresponds to water $\left(\rho=1 \mathrm{~g} / \mathrm{cm}^{3}\right)$. Hence, the CT value shows that the constituents of the bubble are lighter than water. Considering that the core samples are completely coated by paraffin, it is most likely that the bubble is composed mainly of methane gas and water. The water contents in the bubbles vary, but insignificantly, judging from the CT value distribution. In particular, the peak suggesting water is rarely identified in the other bigger bubbles.

\section{Pore-Water Chemistry}

Pore-water chemistry analysis was performed to understand the quality of water that came into the fluidized unit. The pore-water samples were taken from the fluidized and the unfluidized units with care, excluding the marginal part to prevent contamination by seawater. The chlorinity content of the pore water squeezed from Section $155-941 \mathrm{~B}-6 \mathrm{H}-4$ of the fluidized unit was $481 \mathrm{mM}$, whereas that of the unfluidized unit was $559 \mathrm{mM}$, which corresponds to 1.16 times more chlorinity. It is significant that the content of the other elements, including $\mathrm{Na}, \mathrm{NH}_{4}{ }^{+}, \mathrm{K}, \mathrm{Mg}, \mathrm{Ca}$, and $\mathrm{SO}_{4}$, in the pore water taken from the unfluidized unit was also lower than that of the fluidized unit. The ratios of the content of those elements between the fluidized and unfluidized units vary between 1.16 in $\mathrm{Ca}$ and 1.04 in $\mathrm{K}$ as shown in Table 2 . The greatest ratio of $1.16, \mathrm{Cl}$ and $\mathrm{Ca}$, suggests that the anomalous pore-water chemistry in the fluidized sediment can be explained by dilution of $\sim 14 \mathrm{vol} \%$ freshwater. It demonstrates that fluidization was not caused by "flow-in" during APC coring. 


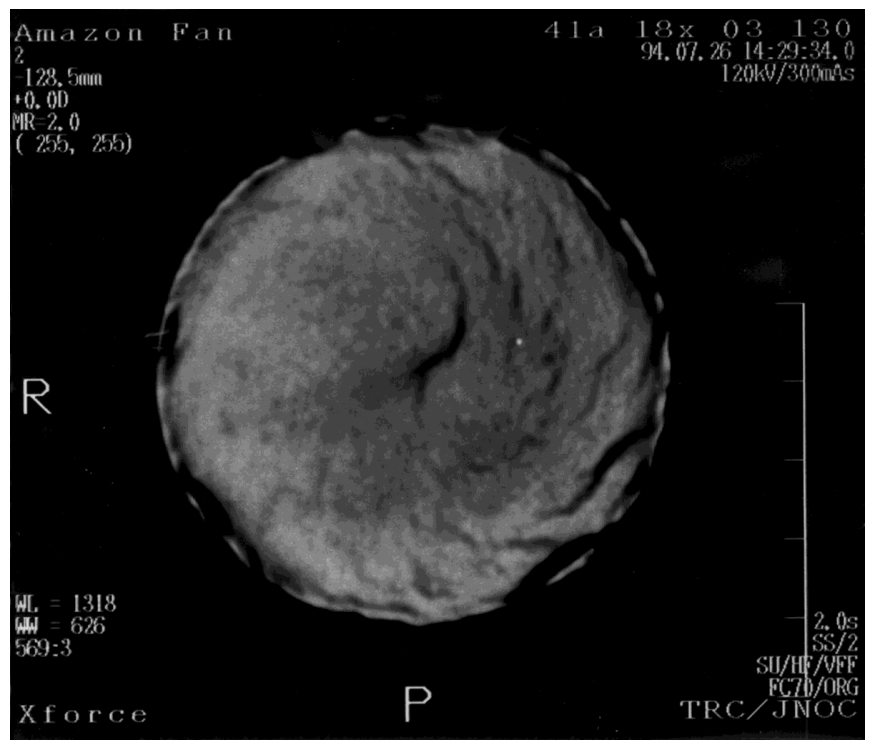

Figure 6. A CT vertical-profile image showing artifacts due to XCB core disturbance. There are many sigmoidal open fissures. Such sigmoidal shear is commonly developed in the XCB cores. The longitudinal profile is shown in Figure 4 . Window width $=626$; window level $=1318$.

\section{DISCUSSION}

The results of the CT scan and pore-water chemistry analyses suggest that the fluidized part of Section 155-941B-6H-4 is produced by the invasion of freshwater together with large amounts of methane gas into the original unfluidized sediments. The methane gas in the bubble should be different from the dissolved methane that is extruded from the pore water, which is associated with the pressure release that caused the gas expansion-induced fractures. This is because the formation of the bubbles took place after the formation of the gas expansion-induced fractures. The fluidization thus occurred later than the formation of the gas expansion-induced open fractures. A possible explanation is that the fluidization took place when the gas hydrate disassociated, and the gas hydrate-induced high water-content fluidized sediment could move upward like a plume from the bottom of the fluidized unit because the mixture of freshwater, gas, and sediments would be lighter than the surrounding sediments. This is consistent with the occurrence of large gas bubbles that are concentrated particularly on the top of the core samples. It is most likely therefore that the disassociation of the gas hydrate occurred during shipboard storage in the core rack before the core temperature was raised to room temperature, so that the MST measurements could be made.

Two modes of occurrence of gas hydrate in a fine-grained sediment are possible: (1) gas hydrate dispersed as small particles coexisting with pore water in the pores or (2) gas hydrate was included as a relatively larger nodule. For this, the CT image of Section 155941B-6H-4, showing a plume-like shape of the fluidized sediment provides a clear explanation. The coexistence of the fluidized and unfluidized units, and the chlorinity anomaly in the pore water, shows the significant inhomogeneity of the gas hydrate in the sediment. If such homogeneity were absent so that the gas hydrate was evenly distributed in the sediment as small particles included in the pores, it would be impossible to elucidate the origin of the plume-shaped fluidization and the significant gap in chlorinity in the pore water between both units. This is also supported by the "oatmeal-like" texture found only in the boundary between the fluidized and unfluidized units.

Nine CT values were carefully obtained from the fluidized unit excluding bubbles (Table 3). They range from 879 to 957 units with

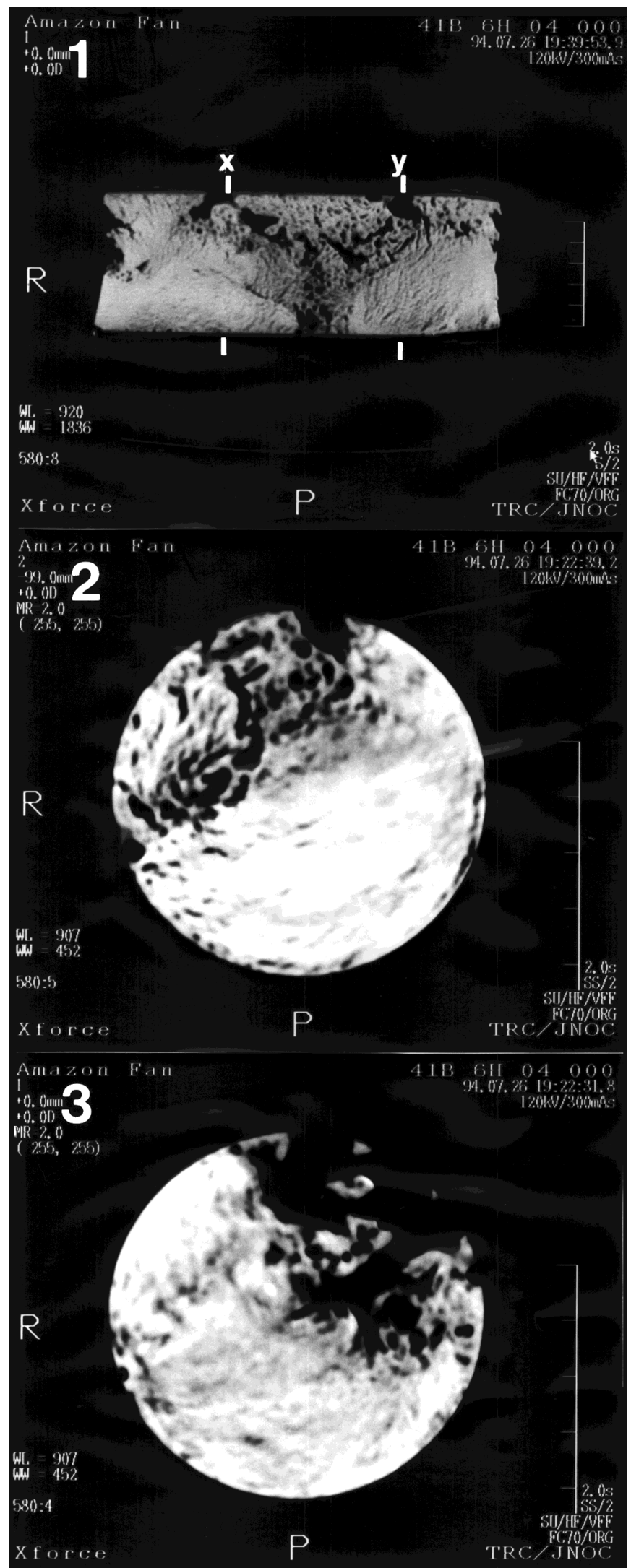

Figure 7. Three CT images of Sample 155-941B-6H-4, 0-20 cm, showing plume-like shape fluidization structure with bubbles. Panel 1 is a longitudinal profile (window width: 920; window level: 1836), panels 2 and 3 are vertical profiles (window width $=452$; window level $=907$ ). The locations of panels 2 and 3 are shown in $x$ and $y$, respectively. 

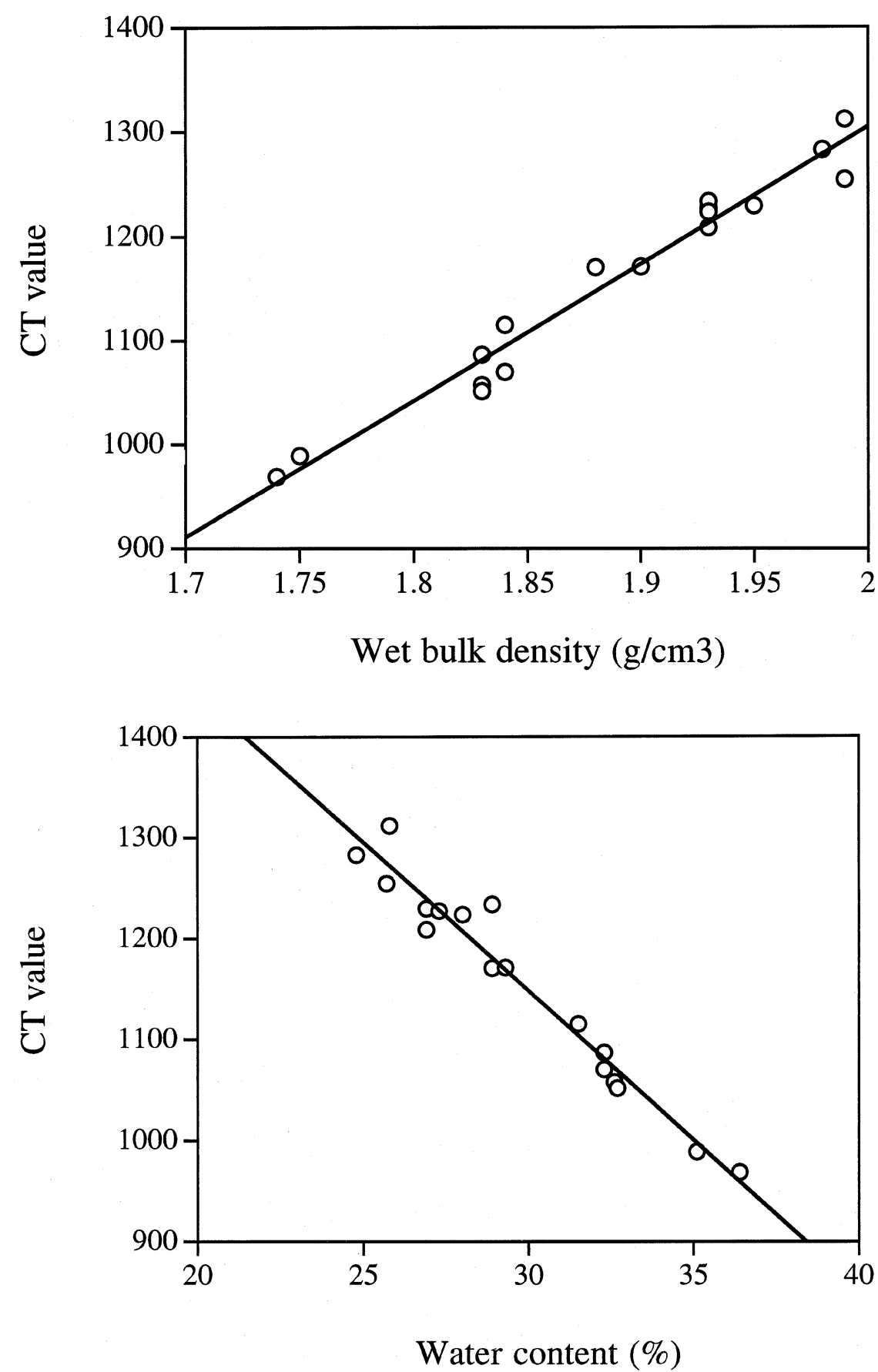

Figure 8. Graph showing the relationship between CT value and the wet bulk density.
Figure 9. Graph showing the relationship between CT value and water content. an average of 913 units. In comparison, five CT values that were obtained from the unfluidized unit range from 1147 to 1080 units, with an average of 1123 units. The density of the unfluidized unit was calculated, using Equation 2, as $1.86 \mathrm{~g} / \mathrm{cm}^{3}$, whereas the density of the fluidized unit was calculated as $1.70 \mathrm{~g} / \mathrm{cm}^{3}$. Hence, the density contrast between the fluidized and unfluidized units is $0.16 \mathrm{~g} / \mathrm{cm}^{3}$. This density contrast would cause a density imbalance in the sediment, and the fluidized material would move upward as a plume. Based on Equation 3, the difference in CT values also enables us to estimate the difference in water content of both units. The water content of the fluidized unit was $38.0 \%$, whereas the water content of the unfluidized unit was $30.8 \%$. The difference of the water content between the unfluidized and fluidized units thus was estimated to be $7.2 \%$. This suggests that the sediment was diluted by $7.2 \%$ freshwater derived from the gas hydrate. The total amount of the gas hydrate-induced fresh- water can also be estimated using the chlorinity anomaly (e.g., Behrmann, Lewis, Musgrave, et al., 1992). In Section 155-941B-6H-4, the freshwater content was estimated to be $\sim 14 \%$ of the total pore-water content as described above. The porosity obtained from Section $155-$ 941B-6H-4 ranges from 0.52 to 0.55 (Shipboard Scientific Party, $1995 b$ ). Assuming that the original porosity is 0.52 , the water content of the sediment associated with gas hydrate-induced freshwater should increase $7.2 \%$. It is thus possible to say that the value of the water content estimated from the CT value is consistent with that obtained from the pore-water chemistry.

Let us consider that the volume change of hydrate disassociation. $0.8 \mathrm{~m}^{3}$ of freshwater can be produced by the disassociation of $1 \mathrm{~m}^{3}$ of methane hydrate in the case of a fully saturated structure-I methane hydrate (Kvenvolden, 1993). Using the relationship of the volume change between the gas hydrate and the freshwater dissolved, it is 


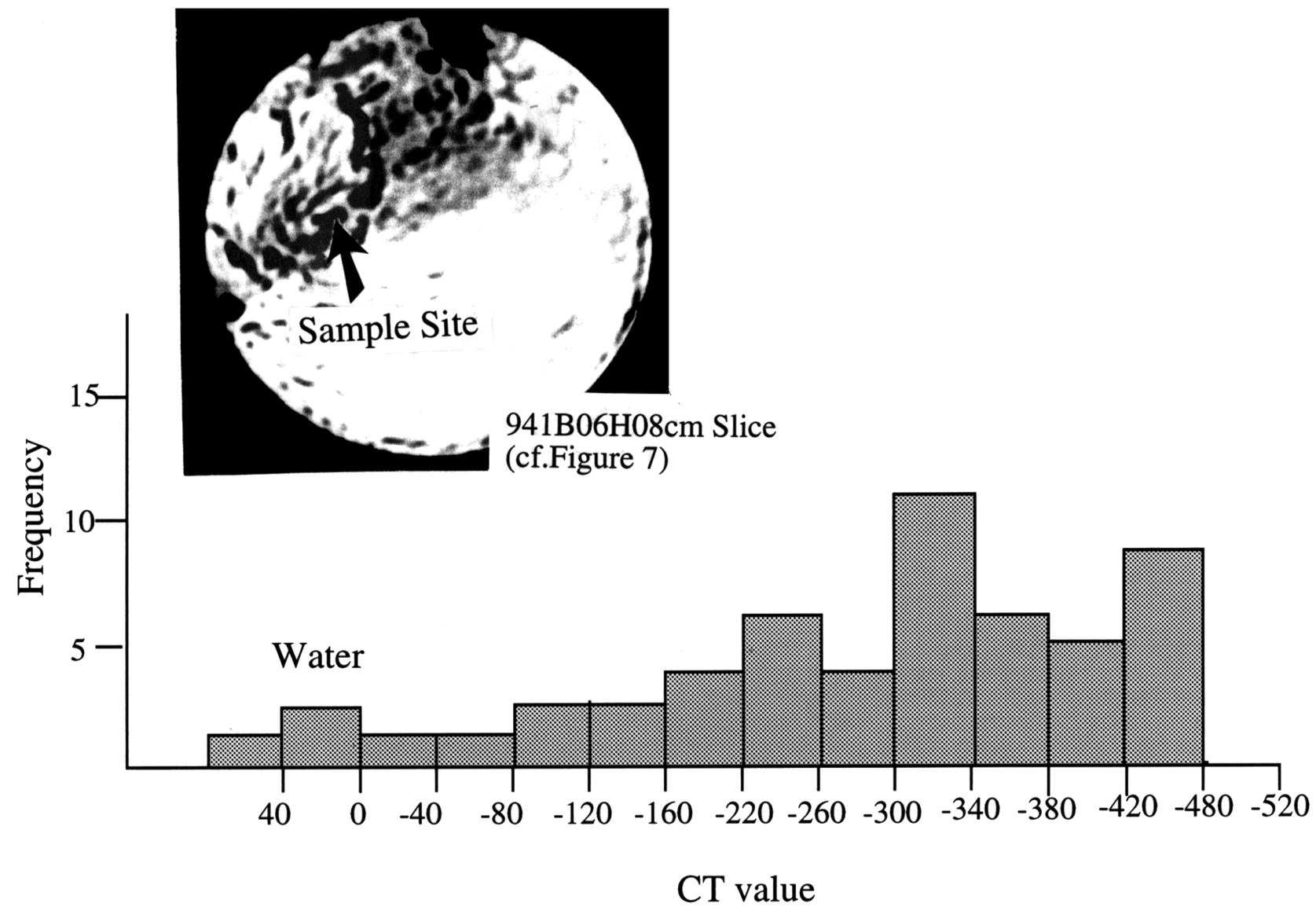

Figure 10. Histogram of CT value, pixel by pixel, obtained from a small bubble in Sample 155-941B-6H-4, 0-20 cm. A peak is seen around 0, suggesting the presence of water. Other negative values show the mixture of gas (methane) and probably water vapor. Note sample site in upper left.

Table 2. Results of the pore-water chemical analysis of Sample 155-941B-6H-4., 0-20 cm.

\begin{tabular}{lccccccc}
\hline \multicolumn{1}{c}{$\begin{array}{c}\text { Core, section, } \\
\text { interval }(\mathrm{cm})\end{array}$} & $\begin{array}{c}\mathrm{Cl} \\
(\mathrm{mM})\end{array}$ & $\begin{array}{c}\mathrm{SO}_{4} \\
(\mathrm{mM})\end{array}$ & $\begin{array}{c}\mathrm{Na} \\
(\mathrm{mM})\end{array}$ & $\begin{array}{c}\mathrm{NH}_{4} \\
(\mathrm{mM})\end{array}$ & $\begin{array}{c}\mathrm{K} \\
(\mathrm{mM})\end{array}$ & $\begin{array}{c}\mathrm{Mg} \\
(\mathrm{mM})\end{array}$ & $\begin{array}{c}\mathrm{Ca} \\
(\mathrm{mM})\end{array}$ \\
\hline 155-941B- & & & & & & & \\
5H-4, 0-20 (reference) & 512.8 & n.d. & 504.3 & 3.3 & 8.8 & 40.0 & 3.8 \\
6H-4, 0-20 unfluidized & 558.5 & 6.4 & 444.1 & 3.4 & 8.5 & 36.4 & 4.2 \\
6H-4, 0-20 fluidized & 480.5 & 5.6 & 406.2 & 3.2 & 8.2 & 32.6 & 3.6 \\
Unfluidized/fluidized ratio & 1.16 & 1.14 & 1.09 & 1.06 & 1.04 & 1.12 & 1.17 \\
\hline
\end{tabular}

Note: n.d. = no data

possible to estimate that the volume of the hydrate will be $\sim 10 \%$ of the total volume $(\sim 17.5 \%$ of the pore space). Considering the occurrence of Section 155-941B-6H-4 that was taken from the top of the 2-m-thick soupy sediment, the hydrate content in the 2-m-thick soupy zone of the interval from 47 to 49 mbsf could reach up to $10 \%$ of the total volume because the water content would be higher than that of Section 155-941B-6H-4. The percentage of gas hydrate content in sediments is thought to increase from the top of the gas hydrate to above the bottom-simulating reflectors (BSRs; e.g., Rowe and Gettrust, 1993). For example, the gas hydrate content of the highest above the BSR reaches $\sim 18 \%$ of the pore space in the vicinity of the Chile Triple Junction (Bangs et al., 1993). In Site 997 in the Blake Outer Ridge, the highest hydrate content reaches $\sim 8.4 \%$ of the total volume above the BSR (Leg 164; Shipboard Scientific Party, 1996). From the comparison with this data, it is possible to mention that the percentage of gas hydrate content in the 2-m-thick soupy sediments is significantly high, as equivalent to the highest peak values above the BSR.
The source area of the WMTD is best understood in the MTDs in the Amazon Fan (Damuth and Embley, 1981; Damuth et al., 1988; Piper et al., Chapter 6, this volume). The strata updip of the WMTD are well preserved in the continental slope off the Amazon Canyon, and the WMTD is bounded by scarps up to $200 \mathrm{~m}$ high. The distribution of BSR is limited to the area upslope from the WMTD along the Amazon Canyon in water depths shallower than 2000 m (Manley and Flood, 1988; Fig. 1). The bathymetric map shows that small diapirlike structures protrude upward from the BSR, and in places, pierce the seafloor from small domes $10-20 \mathrm{~m}$ high. Figure 11 is a seismic profile showing the BSR across the headscarp of the WMTD. Many normal faults are recognized, and it is likely that thick sediments, including the BSR, have been displaced from the headscarp of the WMTD. Downslope from this scarp, a large slump (or slide) block is also identified, which corresponds with the very proximal slump area of the WMTD (their central debris flow) identified by Damuth et al. (1988). If Section 155-941B-6H-4 and the 2-m-thick soupy sediment were derived from above the BSR, they should correspond to a part 
Table 3. Detailed CT values obtained from the domains of the unfluidized and fluidized units, Sample 155-941B-6H-4, 0-20 cm.

\begin{tabular}{crrr}
\hline Sample sites & $\begin{array}{c}\text { CT } \\
\text { value }\end{array}$ & $\begin{array}{c}\text { Standard } \\
\text { deviation }\end{array}$ & $\begin{array}{c}\text { Confidence } \\
(0.05)\end{array}$ \\
\hline Unfluidized unit & 1147.49 & 30.26 & 29.65 \\
average: 1123 & 1130.03 & 4.93 & 4.83 \\
& 1110.70 & 17.23 & 16.89 \\
& 1079.41 & 49.44 & 48.45 \\
& 1146.24 & 12.11 & 11.87 \\
Fluidized unit & 933.76 & 8.07 & 7.91 \\
average: 913 & 927.35 & 10.11 & 9.91 \\
& 933.24 & 11.07 & 10.85 \\
& 956.62 & 10.47 & 10.26 \\
& 910.14 & 5.62 & 5.51 \\
& 878.35 & 8.10 & 7.94
\end{tabular}

Note: $\mathrm{CT}=$ computed tomography

of "missing" sediment above the BSR inferred from seismic-reflection profiles of the source area.

In regions of gas hydrate, a sea-level lowering decreases pressure along the gas-hydrate phase transition, BSR, thus initiating a dissociation of gas hydrate and consequently releasing large volumes of bubble-phase gas into the sediment directly beneath the hydrate base. The gas-augumented pore pressure near the BSR thus remains almost as great as during the high sea level. It causes abnormal pore pressure, thus weakening sediment strength (cf. Kayen and Lee, 1993). In the case of the WMTD, the timing to cause the slope failure was during the LGM or during the preceding sea-level fall when the BSR was located on the shallowest horizon. From this, we can conclude that the disassociation of gas hydrate was the most important trigger mechanism for causing the regionally extensive slope failure that produced the WMTD.

\section{CONCLUSIONS}

X-ray CT and pore-water chemistry analyses were performed using whole round-core samples from the regionally extensive WMTD, Site 941 of Leg 155, on the Amazon Fan. The following conclusions can be drawn from this report:

1. Although the core samples suffered from gas expansion-induced artifacts, the CT value obtained from the ROI has good correlation with the bulk density and water content of the sediment samples.

2. The CT image obviously shows a plume-shaped, fluidized structure with gas bubbles in the gassy mud sediment, Sample $155-941 \mathrm{~B}-6 \mathrm{H}-4,0-20 \mathrm{~cm}$, at $\sim 47 \mathrm{mbsf}$. This corresponds to the top of the 2-m-thick soupy and gassy sediment. An increase of $\sim 7.2 \mathrm{vol} \%$ in the water content of the sediment was recognized in the fluidized sediment when compared with those of the surrounding unfluidized sediments. The bulk density of the fluidized sediment decreases $\sim 0.16 \mathrm{~g} / \mathrm{cm}^{3}$. The anomalous pore-water chemistry indicates that the fluidized sediment can be explained by the dilution of $\sim 14 \%$ freshwater by total volume of the pore water. The porosity of the sediment ranges from 0.52 to 0.55 . Assuming that the porosity $0.52,7.2$ vol\% in water content of the sediment, is equivalent to 14 vol\% of the pore water, then the various estimates are consistent.

3. The fluidized sediment was produced by the disassociation of a relatively large nodule of gas hydrate. The quantitative CT value analysis allows us to estimate that the percentage of gas hydrate content reached $\sim 10$ vol\% of the total volume and $\sim 17.5 \mathrm{vol} \%$ of the pore space in the fluidized sediment. Because the 2-m-thick soupy sediment was much more fluid than Sample 155-941B-6H-4, 0-20 cm, then the hydrate content of the underlying 2 -m-thick soupy sediment would be higher than the $10 \mathrm{vol} \%$ of the total volume. This content seems to be equivalent to the highest contents of the hydrate above the BSRs reported in the Chile Triple Junction and the Blake Outer Ridge.

4. The continental slope updip of the WMTD is bounded by scarps up to $200 \mathrm{~m}$ high and hummocky topography associated with slides and blocks is developed downslope. The distribution of the BSR is limited to upslope of the WMTD along the Amazon Canyon in shallower than $2000 \mathrm{~m}$ of water depth. If Section 155-941B-6H-4 and the 2-m-thick soupy sediment were derived from above the BSR, then they should correspond to a part of "missing" sediment above the BSR inferred from seismic-reflection profiles of the source area. This leads to the conclusion that the disassociation of gas hydrate is the most important trigger mechanism for causing the regionally extensive slope failure that produced the WMTD.

\section{ACKNOWLEDGMENTS}

I thank the Shipboard Scientific Party of Leg 155 for the cooperative scientific effort that made this study possible. This study was supported by the Technology Research Center, Japan National Oil Corporation, Chiba, including K. Okatsu and T. Munakata. I acknowledge C. Pirmez for the seismic profile and Y. Masuda, H. Baba, and H. Yuzuriha, who assisted me with the technical aspects of this study, and M. Otsubo and T. Masuzawa for supporting the pore-water analysis. This research was supported by Monbusho grant (06452095).

\section{REFERENCES}

Anderson, S.H., Gantzer, C.J., Boone, J.M., and Tully, R.J., 1988. Rapid nondestructive bulk density and soil-water content determination by computed tomography. Soil Sci. Soc. Am. J., 52:35-40.

Bangs, N.L.B., Sawyer, D.S., and Golovchenko, X., 1993. Free gas at the base of the gas hydrate zone in the vicinity of the Chile triple junction. Geology, 21:905-908.

Behrmann, J.H., Lewis, S.D., Musgrave, R.J., et al., 1992. Proc. ODP, Init. Repts., 141: College Station, TX (Ocean Drilling Program).

Boespflug, X., Long, B.F.N., and Occhietti, S., 1995. CAT-scan in marine stratigraphy: a quantitative approach. Mar. Geol., 122:281-301.

Damuth, J.E., and Embley, R.W., 1981. Mass-transport processes on the Amazon Cone: western equatorial Atlantic. AAPG Bull., 65:629-643.

Damuth, J.E., and Flood, R.D., 1985. Morphology, sedimentation processes, and growth pattern on the Amazon deep-sea fan. Geo-Mar. Lett., 3:109117.

Damuth, J.E., Flood, R.D., Kowsmann, R.O., Belderson, R.H., and Gorini, M.A., 1988. Anatomy and growth pattern of Amazon deep-sea fan as revealed by long-range side-scan sonar (GLORIA) and high-resolution seismic studies. AAPG Bull., 72:885-911.

Damuth, J.E., Kolla, V., Flood, R.D., Kowsmann, R.O., Monteiro, M.C., Gorini, M.A., Palma, J.J.C., and Belderson, R.H., 1983. Distributary channel meandering and bifurcation patterns on Amazon deep-sea fan as revealed by long-range side-scan sonar (GLORIA). Geology, 11:94-98.

Flood, R.D., and Damuth, J.E., 1987. Quantitative characteristics of sinuous distributary channels on the Amazon deep-sea fan. Geol. Soc. Am. Bull., 98:728-738.

Flood, R.D., Manley, P.L., Kowsmann, R.O., Appi, C.J., and Pirmez, C., 1991. Seismic facies and late Quaternary growth of Amazon submarine fan. In Weimer, P., and Link, M.H. (Eds.), Seismic Facies and Sedimentary Processes of Submarine Fans and Turbidite Systems: New York (Springer), 415-433.

Galloway, W.E., Dingus, W.F., and Paige, R.E., 1991. Seismic and depositional facies of Paleocene-Eocene Wilcox Group submarine canyon fills, Northwest Gulf Coast, U.S.A. In Weimer, P., and Link, M.H. (Eds.), Seismic Facies and Sedimentary Process of Submarine Fans and Turbidite Systems: New York (Springer-Verlag), 247-272.

Holler, P., and Kogler, F.-C., 1990. Computed tomography: a nondestructive, high-resolution technique for investigation of sedimentary structures. Mar. Geol., 91:263-266. 
Hunt, P.K., Engle, P., and Bajsarowicz, C., 1988. Computed tomography as a core analysis tool: Applications, instrument evaluation, and image improvement techniques. J. Pet. Technol., Sept.:1203-1210.

Kayen, R.E., and Lee, H.J., 1993. Slope stability in regions of sea-floor gas hydrate. In Schwab, W.C., Lee, H.J., and Twichell, D.C. (Eds.), Submarine Landslides: Selected Studies in the U.S. Exclusive Economic Zone. U.S. Geol. Surv. Bull., 2002:97-103.

Kvenvolden, K.A., 1993. Gas hydrates: geological perspective and global change. Rev. Geophys., 31:173-187.

Manley, P.L., and Flood, R.D., 1988. Cyclic sediment deposition within Amazon deep-sea fan. AAPG Bull., 72:912-925.

McCullough, E.C., 1975. Photon attenuation in computed tomography. Med. Phys., 2:307-320.

Orsi, T.H., Edwards, C.M., and Anderson, A.L., 1993. X-ray computed tomography: a nondestructive method for quantitative analysis of sediment cores. J. Sediment. Res., A64:690-693.

Petrovic, A.M., Siebert, J.E., and Rieke, P.E., 1982. Soil bulk density analysis in three dimensions by computed tomographic scanning. Soil. Sci. Soc. Am. J., 46:445-450.

Pogossian, T., Phelps, M.M., and Browell, G.L., 1977. Reconstruction Tomography in Diagnostic Radiology and Nuclear Medicine: Baltimore (Univ. Park Press).

Rowe, M.M., and Gettrust, J.F., 1993. Fine structure of methane hydratebearing sediments on the Blake Outer Ridge as determined from deeptow multichannel seismic data. J. Geophys. Res., 98:463-473.

Shipboard Scientific Party, 1994. Site 892. In Westbrook, G.K., Carson, B., Musgrave, R.J., et al., Proc. ODP, Init. Repts., 146 (Pt. 1): College Station, TX (Ocean Drilling Program), 301-378.
, 1995a. Explanatory notes. In Flood, R.D., Piper, D.J.W., Klaus, A., et al., Proc. ODP, Init. Repts., 155: College Station, TX (Ocean Drilling Program), 47-81.

, 1995b. Leg synthesis. In Flood, R.D., Piper, D.J.W., Klaus, A., et al., Proc. ODP, Init. Repts., 155: College Station, TX (Ocean Drilling Program), 17-21.

1995c. Site 941. In Flood, R.D., Piper, D.J.W., Klaus, A., et al., Proc. ODP, Init. Repts., 155: College Station, TX (Ocean Drilling Program), 503-536.

1996. Site 997. In Paull, C.K., Matsumoto, R., Wallace, P.J., et al., Proc. ODP, Init. Repts., 164: College Station, TX (Ocean Drilling Program), 277-334.

Soh, W., Byrne, T., Taira, A., and Kono, A., 1993. Computed tomography (CT) scan image analysis of Site 808 cores: structural and physical property implications. In Hill, I.A., Taira, A., Firth, J.V., et al., Proc. ODP, Sci. Results, 131: College Station, TX (Ocean Drilling Program), 135140.

Weimer, P., 1989. Sequence stratigraphy of the Mississippi Fan (Plio-Pleistocene), Gulf of Mexico. Geo-Mar. Lett., 9:185-272.

Date of initial receipt: 4 December 1995

Date of acceptance: 7 June 1996

Ms 155SR-231 


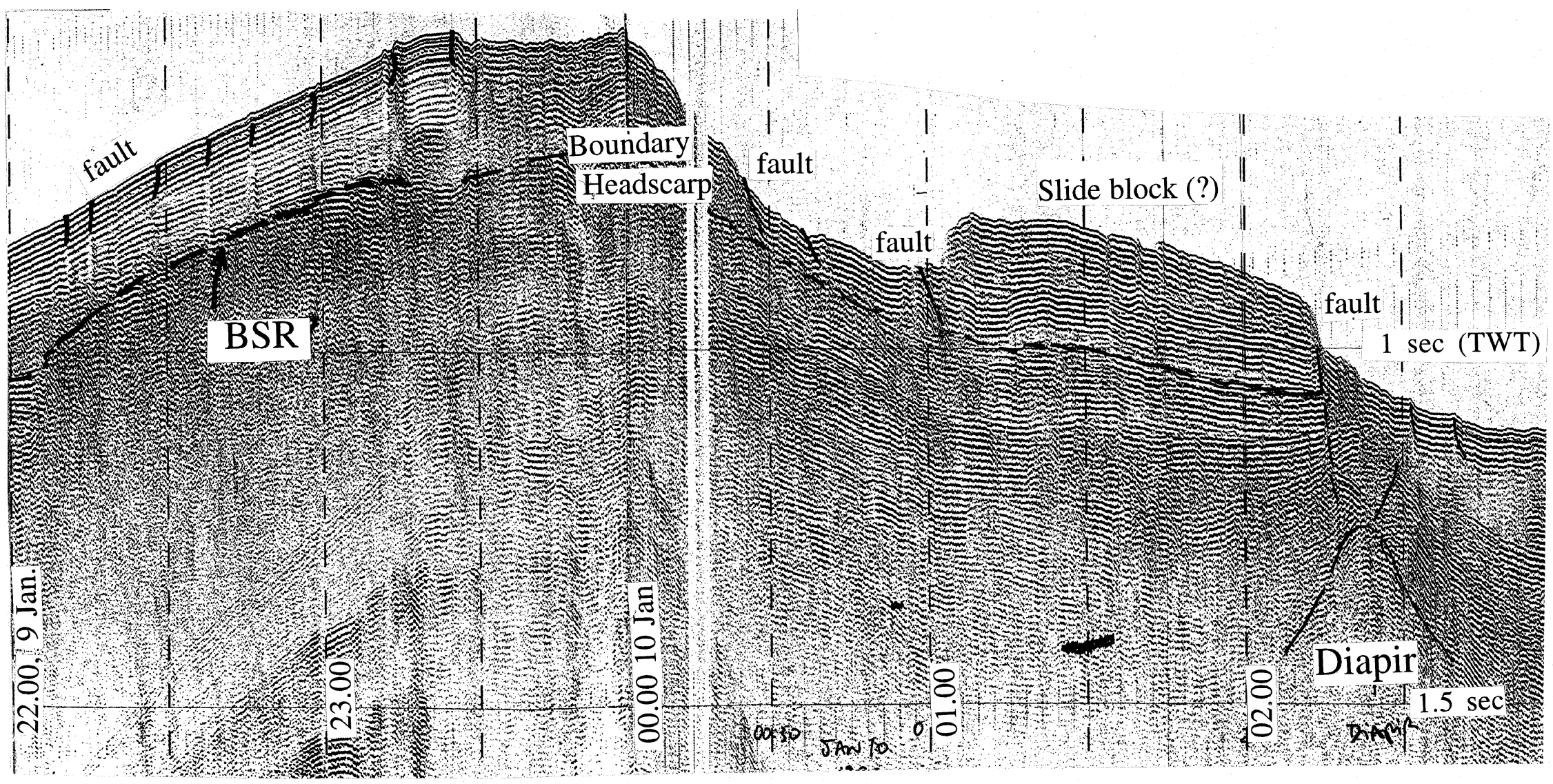

Figure 11. An interpretation of the seismic-reflection profile, showing the development of a bottom-simulating reflector across the source area of the Western Debris-Flow deposit. Data were obtained during Cruise Farnella 81-5 (from 22.00, 9 Jan. to 03.00, 10 Jan. 1982). 